2008

\title{
Market Power Without A Large Market Share: The Role of Imperfect Information and other "Consumer Protection" Market Failures
}

Robert H. Lande

University of Baltimore School of Law, rlande@ubalt.edu

Follow this and additional works at: http://scholarworks.law.ubalt.edu/all_fac

Part of the Antitrust and Trade Regulation Commons

\section{Recommended Citation}

Market Power Without A Large Market Share: The Role of Imperfect Information and other "Consumer Protection" Market Failures, reprinted in Consumer Legal Encounters 138 (2008, D. Naresh Kumar, Ed) (Icfia University Press, Hyderabad, India)

This Book Chapter is brought to you for free and open access by the Faculty Scholarship at ScholarWorks@University of Baltimore School of Law. It has been accepted for inclusion in All Faculty Scholarship by an authorized administrator of ScholarWorks@University of Baltimore School of Law. For more information, please contact snolan@ubalt.edu. 
The American Antitrust Institute

AAI Working Paper No 07-06

Title: Market Power Without A Large Market Share: The Role of Imperfect Information and other "Consumer Protection" Market Failures

Author: Robert H. Lande, Venable Professor of Law, University of Baltimore School of Law, and Director, American Antitrust Institute.

Abstract: There are two very different sources of market power in antitrust cases. The first is traditional market sharebased market power. Market power in antitrust cases also can come from deception, significantly imperfect or asymmetric information, or other types of market failures that usually are associated with consumer protection violations.

When these "consumer protection" market failures are present in antitrust cases, market power can arise even if no firm has a market share large enough for a finding of traditional market share based market power. However, instead of traditional end-use consumers being harmed, the direct victims are businesses.

The "consumer protection" type of market power has been a small part of the antitrust world for decades. Nevertheless, this paper urges that it play an even larger role in the dayto-day world of antitrust. This paper also discusses some of the implications that could arise if we grant this source of market power the attention it deserves. In addition to having an effect on our beliefs as to when market power may be present, it also could have important effects on such related antitrust areas as market definition and entry analysis.

Date: March 14, 2007

Keywords: market power, monopoly power, market failure

Author Contact: rlande@ubalt.edu

AAI Working Papers are works in progress that are intended for later revision and publication. Working Papers do not necessarily represent the position of the American Antitrust Institute. 
Market Power Without A Large Market Share: The Role of Imperfect Information and other "Consumer Protection" Market Failures

Robert H. Lande ${ }^{1}$

March 8, 2007

There actually are two very different sources of market power in antitrust cases. The first is traditional market share-based market power.

Market power in antitrust cases also can come from deception, significantly imperfect or asymmetric information, unduly large transaction costs, or from other types of market failures that usually are associated with consumer protection violations.

However, instead of traditional end-use consumers being harmed, the victims of this deception or imperfect information are businesses. Since this can result in harm to competition in entire markets, including higher prices, and these harms may not be prevented by competition in the relevant markets, they quite properly can give rise to antitrust violations.

In antitrust cases, when these "consumer protection" market failures are present, market power can arise even if no firm has a market share large enough for a finding of traditional market share based market power. Although these two manifestations of market power have very different origins, either type produces the same result. Either can give the firm possessing it the power to raise prices.

The "consumer protection" type of market power has been a small part of the antitrust world for decades. It certainly is used from time to time in mainstream antitrust cases. The purpose of my Testimony will be to urge that it play an even larger role in the day-to-day world of antitrust, perhaps

1 Venable Professor of Law, University of Baltimore School of Law, and Director, American Antitrust Institute. The author's e-mail address is rlande@ubalt.edu. The author is grateful to John Connor, Albert Foer, and Thomas Krattenmaker for extremely insightful comments, and to Alice Arcieri and $\mathrm{J}$. Andrew Stevens for helpful research assistance. 
almost as large as the role it plays in consumer protection law.

At the end I will discuss some of the implications that could arise for antitrust if we grant this source of market power the attention it deserves. In addition to having an effect on our beliefs as to when market power may be present, it also could have important effects on such related antitrust areas as market definition and entry analysis.

I. Market Power Requires A Market Failure.

\section{A. Market Power From Large Market Shares}

The conventional definition of market power is usually expressed as "the power to raise price". ${ }^{2}$ or, colloquially, one subject to pure competition takes its prices from the interplay of supply and demand, while one with market power has some amount of discretion to set its own price. The key distinction for purposes of my Testimony involves the issue of from where the discretion arises.

In the antitrust world, when we say "market power" we almost always mean "market share based" market power. And, of course, a firm can only have market share based market power if it has a market share of at least $40 \%$ (or $60 \%$ or $90 \%$ or whatever percentage of a relevant market is believed to be enough). Even if some critical market share is reached, of course, the firm has the power to raise prices ${ }^{3}$ only if entry

2 See, e.g., NCAA v. Board of Regents, 468 U.S. 85, 109 n.8 (1984). By contrast, monopoly power is usually defined as "the power to control prices or exclude competition." See United States V. E.I duPont de Nemours \& Co., 351 U.S. 377, 391 (1956). This testimony will not attempt to differentiate market power from monopoly power. For a fuller and more precise definition of these terms in general and relative to one another see Thomas G. Krattenmaker, Robert H. Lande \& Steven C. Salop, Market Power and Monopoly Power In Antitrust Law, 76 Geo. L.J. 241 (1987).

3 Moreover, price issues are not the only considerations. Market power also can distort non-price attributes anticompetitively even if price is unaffected. See Neil W. Averitt \& Robert $\mathrm{H}$. Lande, Using The "Consumer Choice" Approach To Antitrust Law, 74 Antitrust L.J. 175 (2007). 
is difficult and other conditions are met. ${ }^{4}$ Even a large market share only gives a firm the traditionally-defined power to raise prices when a significant market failure is present. ${ }^{5}$ If the market is working well even a firm with a $100 \%$ market share might have no ability to raise prices above the competitive level for a significant period. ${ }^{6}$

4 This statement will not discuss product differentiation, and whether it can create space between certain products and potential substitutes in the eyes of some purchasers.

${ }^{5}$ See Neil W. Averitt \& Robert H. Lande, Consumer Sovereignty: A Unified Theory of Antitrust and Consumer Protection Law, 65 Antitrust L.J. 713 (1997). "A leading scholar of the subject, Edwin Mansfield, believes that perfect competition requires four conditions: product homogeneity, relatively small buyers and sellers, mobile resources, and perfect information. Jack Hirshleifer has considered the converse situation and provided a list of three possible imperfections that can prevent a market from functioning perfectly: imperfect information, time lags, and transaction costs. Significant problems in any of these areas can cause competition to be suboptimal."

"Additional market failures are added to some other lists. These further potential problems include coerced decisionmaking, barriers to the entry of new firms, circumstances of natural monopoly, positive or negative externalities, and situations involving 'public goods', 'free riders', 'prisoner's dilemmas', 'lemons', and adverse selection. Despite disputes over taxonomy, this basic list of factors that can plausibly cause competition to become suboptimal is relatively noncontroversial."

"Far more controversial is the question of just how often market failures occur and, therefore, how often remedial action under the antitrust or consumer protection statutes might be appropriate." Id. at 724-26.

6 Such markets often are termed "contestable markets". As the American Antitrust Institute noted in its views about contestability in its statement on Concentration: "There is reason to doubt the empirical significance of the strongest version of the 'contestable market' theory, which holds that potential entry can cause even a monopolist benefiting from significant economies of scale to price competitively. This theory wrongly assumes both that entry requires no significant 
Theoretically, in a perfect, frictionless world, businesses could merge to monopoly or meet and fix prices. This would result in a technical violation of the antitrust laws. But it could not substantially harm consumer welfare because perfect information among businesses and an absence of transaction costs would allow some to quickly enter monopolized or price-fixed markets and compete away supracompetitive margins.

What makes antitrust injury possible in these circumstances is the presence of market failures that are external to consumers. Imperfections in the marketplace, involving capital flows, time lags, search costs, faulty information, and sunk costs, can enable a monopoly or cartel to keep prices elevated for a significant period.?

\section{B. Market Power from "Consumer Protection"} Market Failures

A firm also can obtain the ability to raise prices from the types of market failures most often associated with consumer protection violations. ${ }^{8}$ The most common of these

sunk costs (i.e., the entrant's expenditures on inputs can be fully recovered if entry fails) and that the monopolist's price response to entry is delayed." See http://wWw.antitrustinstitute.org/archives/files/296.pdf

7 See Averitt \& Lande, supra note 5, at 730-33.

8 The FTC has long described the necessary conditions for effective consumer choice in market failure terms when it pursues its consumer protection function:

The various components of the statute form an integrated whole, allowing the Commission to promote the diverse benefits of a free and open economy. Thus the ban on unfair competition prevents exclusionary or anti-competitive behavior and helps preserve a full variety of marketplace options for consumers to choose among; the ban on deception helps ensure that consumers will not make that choice on the basis of misleading information; and the ban on unfair practices ensures that the choice is not distorted by coercion, the withholding of important information, or similar practices. 
fall within five categories: (1) coercion; (2) undue influence; (3) deception; (4) incomplete or asymmetric information; or (5) unreliable, uncertain or overly confusing information. ${ }^{9}$

This list of "consumer protection" market failures is really not all that different from the types of market failures that prevent entry to challenge a monopoly's dominance. However, consumer protection problems cannot occur absent market failures occurring "inside the head" of ultimate purchasers. ${ }^{10}$ Hypothetical purchasers who are perfectly informed, rational, and intelligent can never be subject to consumer protection abuses. Ordinary consumers, however, can have greater difficulties.

It is crucial to note, however, that corporate officials also can be victimized by deception or imperfect information. Sometimes this will only affect that corporation, but occasionally it can hurt competition in that market as a whole.

\section{Can These Constitute Antitrust Violations?}

Can deception and these other market failures give rise to antitrust violations, or should we instead term whatever harms they cause "consumer protection" problems? It all depends upon whether they distort the offerings of the market in question.

This is because all antitrust violations have in common the fact that they all affect or distort the offerings that the market provides. They change the choices that would be offered to consumers by the functioning of the free market

Safeguards at all three levels are needed to ensure that substantial consumer injury is adequately addressed.

Companion Statement on the Commission's Consumer Unfairness Jurisdiction, 4 Trade Reg. Rep. ( $\mathrm{CCH})$ I 13,203 at 20,909-3 (1980).

9 See Averitt \& Lande, supra note 5, at 733.

10 Id. at 729-34. 
competition. ${ }^{11}$ Consumer protection violations, by contrast, detrimentally affect consumers' ability to choose from among the options provided by the market. ${ }^{12}$ When imperfect information, deception or coercion distorts the options offered by the market, this quite properly gives rise to an antitrust violation.

It is crucial to note, however, that these consumer protection violations, flowing from these "consumer protection" market failures, can occur even if the firm committing the act in question does not have a monopoly market share. We prosecute a company that commits consumer fraud even if its market share is small. We prosecute fraudulent companies even if $80 \%$ of the sellers in their market are honest. ${ }^{13}$

The same thing should be done - and is done - when these "consumer protection" market failures give rise to antitrust violations. This happens even if the firms in question do not have a traditionally large market share at the time of the alleged violation. To show how this already occurs in antitrust, I will briefly discuss three well known singlefirm $^{14}$ cases; Kodak, ${ }^{15}$ Rambus, ${ }^{16}$ and Jefferson Parish. ${ }^{17}$ Each

11 Id. at $718-720$.

12 Id. at $720-722$.

13 It is not controversial to note that consumers can be victimized by routine fraud even if $95 \%$ of the sellers in a market are honest. However, if the market generally is working well and if 95\% of the companies in it are honest, the consumer protection function could be required less often than if only $5 \%$ of the firms were honest.

14 For a discussion of collusive cases involving similar information and search cost issues, see Robert H. Lande \& Howard P. Marvel, The Three Types of Collusion: Fixing Prices, Rivals, and Rules, 2000 Wisc. L. Rev. 941, 950-77 (2000).

15 Eastman Kodak Co. v. Image Technical Services, Inc., 504 U.S. 451 (1992).

16 Rambus, Inc., FTC Docket No. 9302 (2006).

17 Jefferson Parish V. Hyde, 466 U.S. 2 (1984). 
involved an alleged antitrust violation by a firm that did not, before the violation, have a monopoly market share as measured conventionally. Each relied upon a market failure that is more often associated with consumer protection violations, such as overly complicated information, a mistake or unexpected change in corporate policy, transaction costs, third party payments, and/or deception. Each presented allegations which, if true, could have resulted in antitrust harms.

\section{Kodak}

Kodak is the antitrust case that most prominently stands for the proposition that market power can arise from information that is imperfect or overly complicated. Kodak also reminds us that just because businesses are involved we should not assume they always will possess information perfect enough to ensure a competitive outcome, or that a market that seems to be competitive, when assessed in terms of traditional market shares, inevitably will supply the necessary information to the marketplace in a full and timely manner.

Kodak involved the firm's requirement that its customers purchase the firm's maintenance services to obtain its spare parts. ${ }^{19}$ What made the Kodak tie-in of special concern was

19 See Eastman Kodak Co. v. Image Technical Services, Inc., 504 U.S. 451 (1992). Kodak had changed its photocopier service policies around 1985, in an effort to limit the growth of independent service organizations. Customers who had bought copiers before the policy change were forced against their expectations to pay higher prices as a result of this new tiein because they were already locked in to using Kodak machines. For a more detailed discussion of this case see Robert $\mathrm{H}$. Lande, Chicago Takes It on the Chin: Imperfect Information Could Play a Crucial Role in the Post-Kodak World, 62 Antitrust L.J. 193 (1993). 
that Kodak was found to have only $20-23 \%$ of the market for sales of copier machines, and thus would not be considered under normal market share standards to hold market power. ${ }^{20}$

A key to the Court's decision was its concern over a possible shift in Kodak's policy that had been unanticipated by its customers, and also over consumers' inability to calculate the life-cycle pricing of their copier repairs and spare parts. Defendant's alleged actions also could be characterized as deceptive, or close to it, because it violated an understanding that users would be allowed to handle maintenance in a certain way over the lifetime of the products. ${ }^{21}$ Due to a lock-in caused by the transaction costs of switching to a different copier, they became vulnerable to exploitation from Kodak's tying arrangement.

Kodak also is significant because it reminded us that it was possible for purchasers who were businesses, not traditional end-use consumers, to be vulnerable to information imperfections and complexities. Just because businesses are involved we should not assume they always will possess information perfect enough to ensure a competitive outcome, or that a market that seems to be competitive when assessed in terms of traditional market shares inevitably will supply the necessary information to the marketplace in a full and timely manner.

Kodak also held that switching costs can mean that the time to measure market power - the ability of the seller of an

${ }^{20}$ Kodak's market share was, not surprisingly, in dispute. The Court found, however, that it had $23 \%$ of the market for new copiers and $20 \%$ of the market for new micrographic equipment. See Image Technical Serv., Inc. V. Eastman Kodak Co., 903 F.2d 612, 616, n.3 (9th Cir. 1990); Image Technical Serv., Inc. $v$. Eastman Kodak Co., 1993 WL 313162, *1 (N.D.Cal.)(Not reported in F. Supp.).

21 This arguable deception by defendant is so important that lower courts have found that full disclosure of such terms can immunize a firm from Kodak liability. See, e.g., Merck Medco Managed Care v. Rite Aid Corp., 1999 WL 691840, *6- ${ }^{*} 9$ (4th Cir. 1999); Cant Strip Corp. v. Schuller Int'l, Inc. 1995 WL 767805, *3-*5 (D.Ariz 1995); Collins v. Int'l Dairy Queen, 980 F.Supp. 1252, 1254-55 (1997); Alexander V. Phoenix Bond \& Indem. Co., 149 F.Supp.2d 989, 998-99 (2001). 
aftermarket product to raise prices - sometimes will be after the product is purchased. In these situations the seller might be found to have market power even if it only has a modest share of the initial product market. ${ }^{22}$

III. Rambus and other cases allegedly involving the deception of standards setting organizations.

A firm that has secured, or knows it is about to secure, a patent on the intellectual property covered by a standard might be able to misrepresent (either expressly or by silence) to a standard setting organization that no such patent exists, thereby inducing the adoption of a technology that relies on the patent and thereby greatly increases its value. The firm might be able to wait until the industry has committed itself to the standard and has become locked in; and then assert its patent rights.

The FTC's case in Rambus involved essentially these allegations. ${ }^{23}$ The FTC held, in effect, that Rambus was guilty

22 The FTC has brought a number of consumer protection cases involving post-hoc contract breaches. Pursuing a tie-in or other antitrust matter in these situations may be appropriate in cases where consumers have been injured by faulty information even if defendants possess no traditionallyassessed market share-based market power at the time of the violation. See Orkin Exterminating Co., 108 F.T.C. 263, 347, 368 (1986) (company breached "lifetime" service contract by raising annual renewal fees when it had promised not to do so); $c f$. FTC v. Certified Merchant Services, Civ. Action No. 4:02cv44, Complaint 28-31 (E.D. Tex.) (unfairness authority invoked to keep small businesses from being held subject to contracts for credit card processing services on unfavorable terms, when the adverse terms had been improperly added to the contracts after signature), available at

http://Www.ftc.gov/os/2002/02/cmscmplnt.pdf. of course, if there is merely a policy change, but no reasonable understanding of any promise that the policy would not be changed, then there is no violation.

23 Rambus, Inc., FTC Docket No. 9302 (2006). See Press Release, Federal Trade Comm'n, FTC Finds Rambus Unlawfully Obtained Monopoly Power, Aug. 2, 2006, available at http://Www.ftc.gov/opa/2006/08/rambus.htm. The Commission pursued a somewhat similar theory against Unocal. See Union 
of illegally monopolizing the relevant markets even though the company might have had no market power before the deception was made - if market power were traditionally defined as requiring a huge market share ${ }^{24}$ of a rigorously defined market. ${ }^{25}$ Moreover, it would have been very difficult to determine defendant's market share at the time of the alleged deception because its patents - or perhaps some other firm's patents - could have become crucial, or could have become worth very little, depending upon the actions of the standard setting organization.

But even if Rambus' pre-deception market power was uncertain if assessed under a conventional market share based approach, the FTC found that it had the power to deceive the standard setting organization in a manner that kept the market from providing the benefits of competition. In this way, it gave itself post-deception monopoly power.

Oil Co., FTC Docket No. 9305. Unocal involved charges that the patent-holding firm deceived a unit of the California state government as well as other industry participants. Unocal eventually agreed to release the relevant patents to the public as part of a settlement with the FTC, in the context of the firm's acquisition by Chevron. See Press Release, Federal Trade Comm'n, Dual Consent Orders Resolve Competitive Concerns About Chevron's \$18 Billion Purchase of Unocal, FTC's 2003 Complaint Against Unocal (June 10, 2005), available at http://www.ftc.gov/opa/2005/06/chevronunocal.htm.

24 A monopolization violation usually requires that defendant possess at least $60 \%$ of a rigorously defined market. See Robert H. Lande, Are Antitrust "Treble Damages" Really Single Damages? 54 OHIo ST. L.J. 115, 149-51 (1993), showing that the average monopolist between 1890 and 1992 had between a 75\% and $85 \%$ market share, with almost none having less than a $60 \%$ share. By contrast, however, monopsony power, on the buyer side, may occur at lower levels of concentration. See Robert H. Lande, Beware Buyer Power, Legal Times, July 12, 2004.

25 Some thought that the market power and market share requirements of monopolization were unclear in, for example, the Dell Computer case See Dell Computer, 121 F.T.C. 616, 632 (1996) (Azcuenaga, Comm'r, dissenting) ("the majority fails to identify the relevant market in which market power assertedly was 'conferred'"). 
IV. Jefferson Parish

Jefferson Parish $v$. Hyde ${ }^{26}$ generalizes the idea that market power can flow from "consumer protection" market failures because it involved market failures other than imperfect or deceptive information.

Jefferson Parish rejected a finding of market power by a firm with a $30 \%$ market share, ${ }^{27}$ holding that this market share was insufficient despite the existence of market imperfections such as high transaction costs (the travel time of patients) and "the prevalence of third party payment for health care costs [which] reduces price competition, and a lack of adequate information". ${ }^{28}$ Even though this case seemed to establish a $30 \%$ market power "safe harbor" in seller cases, it did establish that market failures other than imperfect information potentially can be crucial to a Court's market power determination.

26466 U.S. 2 (1984).

27 Id. at 26 .

28 Id. at 27. The court noted: “East Jefferson's market share alone was insufficient as a basis to infer market power, and buttressed its conclusion by relying on "market imperfections" that permit petitioners to charge noncompetitive prices for hospital services: the prevalence of third party payment for health care costs reduces price competition, and a lack of adequate information renders consumers unable to evaluate the quality of the medical care provided by competing hospitals. While these factors may generate "market power" in some abstract sense, they do not generate the kind of market power that justifies condemnation of tying." (Footnotes omitted.)

Omitted footnote 44 reads: "The Court of Appeals acknowledged that absent these market imperfections, there was no basis for applying the per se rule against tying. The contract at issue here involved only one hospital out of at least twenty in the area. Under the analysis applied to a truly competitive market, appellant has failed to prove an illegal tying arrangement." Id. at 1566.

Omitted footnote 45 reads: "Congress has found these market imperfections to exist." 
V. Overview of Possible Implications

Imperfect information and other transaction costs are everywhere. A crucial issue, however, is how significant they must be before they can constitute a "market failure" that should affect antitrust decisionmaking. ${ }^{29}$ This requires an extremely difficult evaluation - as does the assessment of traditional, market share based market power.

To the extent they exist significantly, however, imperfect information and the other "consumer protection" market failures can give firms some power unilaterally to raise prices above competitive levels. This is because a firm can to some extent be insulated from hard competition from its rivals; a firm can to some extent be insulated from entry by potential entrants, and these factors also can provide a space, cushion, or isolation around consumers similar to that created by market share-based market power. ${ }^{30}$

In all these situations the firms involved still compete, its customers try to get the best deals, and other firms still seek to enter. But the firms compete less effectively, the customers search less effectively, and entry becomes less likely. To the extent these tasks are made more difficult by "consumer protection" market failures, prices can rise. The isolation or cocoon has the same effects that would arise from traditional market share based market power. This cushion whether between firms and consumers, between rivals, or between existing firms and potential entrants - can enable the beneficiary firm to raise prices. ${ }^{31}$ This pricing freedom is the essence of market power.

${ }^{29}$ When is information imperfect enough to affect the choices of a large percentage of customers and detrimentally affect competition in a market? Since information is almost never perfect, this matter of degree can be of the utmost importance.

30 For an extended discussion of these issues see Robert $\mathrm{H}$. Lande \& Howard P. Marvel, The Three Types of Collusion: Fixing Prices, Rivals, and Rules, 2000 Wisc. L. Rev. 941 (2000).

31 Id. 
If antitrust were to take these concepts significantly more seriously than it does today, this could have profound effects on the analysis of market power and related areas.

1. Market Share requirements for market power could change.

Kodak had only $20-23 \%$ of its relevant market. In today's antitrust world, of course, it is almost inconceivable that a firm with double this market share would be found to have traditionally defined market power. Yet, if the allegations in Kodak were true, competition in the market did not protect consumers adequately, and the harms to consumers were serious. When the market imperfections discussed in this Testimony are present, ceteris paribus, a lower market share should be required for a finding of market power or monopoly power.

Another result is that we should be more cautious about establishing substantial market share based safe harbors in the Merger Guidelines or Joint Venture Guidelines, and consider using the existing market share screens more strictly.

2. Markets could be defined differently.

Imperfect information could create more narrowly defined relevant markets because it could effectively prevent customers from turning to certain potential substitutes. Some customers might not know of an option's existence. ${ }^{32}$ If a significant number of potential consumers of plastic conduit, certain types of student loans, or nonflorescent lightbulbs, were unaware of the existence of a close substitute, perhaps the close substitute should not be considered to be within the same relevant product market.

Moreover, some customers might not realize that a certain product is a cost effective option, and for other customers the transaction costs of finding another choice - or customers' beliefs as to the size of these

32 of course, sometimes customers who are good shoppers can drive out fraudulent sellers and in other ways effectively help poor shoppers. 
transaction costs - might be so large that the firm in question has some degree of pricing freedom.

To investigate these questions we should attempt to ascertain the information about the products in question that actually was in the minds of potential customers, rivals, and entrants. This will tell us whether other products effectively function as substitutes. It introduces consumer behavior and therefore marketing expertise into the antitrust equation. All this could lead to markets being defined more narrowly and to larger shares being imputed to certain firms within that market. This could have the effect of making it more likely that particular firms will be found to have market power.

\section{Entry analysis could be significantly affected.}

Entry that can take place within 2 years is considered by the Merger Guidelines to be relatively easy and short term. ${ }^{33}$ However, when we compute this period, we should not always assume that would-be entrants instantly spot the profit opportunity and instantly make the corporate decision to enter. This certainly is not always true. Sometimes it takes a considerable period before a profit opportunity is noticed and a corporation makes and decides to implement a decision to enter a market. Yet, these factors are not considered in the Merge Guidelines. ${ }^{34}$

Imperfect information similarly can affect firms' decisions to enter markets in response to a $5-10 \%$ price rise, and firms' perceptions as to the time required to enter markets. Moreover, the 5-10\% test for both entry and market definition would have to be modified because potential entrant and customer reactions to a 5-10\% price rise would only "count" if they knew the rise was due to market power. By contrast, perceptions that prices rose due to increased costs or other factors

${ }^{33}$ See U.S. Dep't of Justice \& Federal Trade Comm'n, Horizontal Merger Guidelines (1992, revised 1997), 4 Trade Reg. Rep. $(\mathrm{CCH})$ ๆ 13,104, especially Sections 1, available at http://www.ftc.gov/bc/docs/horizmer.htm .

${ }^{34}$ Id. at Sections 1 and 3 . 
would allow firms to increase prices without as much fear of entry or resistance by powerful buyers.

Suppose potentially competing firms do not realize that prices rose due to an increase in the market power of the firm in question, but instead believed prices increased due to cost increases? If they believed the entire price rise was due to cost increases, they might be very reluctant to enter. In these markets the information imperfections would mean that a price increase of more than 2 years due to increased market power would not cause entry even though the price rise actually was caused by market power. Thus, the Merger Guidelines "likely" test for entry could be affected, as well as its "timely" test.

VI Conclusions: The Underutilized Source of Market Power

No plaintiff has won an antitrust case at the Supreme court in more than a decade. The expansionist portions of some of the cases I have cited were discussed in their respective opinions mostly just as possibilities, moreover, and they largely have been ignored by the lower courts in recent years.

Nevertheless, consumer protection law's assumptions about individuals' capabilities, vulnerabilities, and needs should apply to businesses (and officials from standard setting organizations, and government officials) as well. Relatively new lines of inquiry should be opened in many antitrust cases, looking for evidence of information imperfections and other "consumer protection" types of market failure. ${ }^{35}$ These

35 Predatory pricing may be impossible without imperfect information. See Richard 0. Zerbe, Jr. \& Donald S. Cooper, An Empirical and Theoretical Analysis of Alternative Predation Rules, 61 TEX. L. Rev. 655 (1982). Zerbe \& Cooper demonstrate that to the extent we believe in the effects of information imperfections, we are more likely to find that predation is possible and likely. 
principles have not been forgotten by the antitrust field, of course, as Rambus and related cases demonstrate. But these principles should be utilized more often.

It would be sound public policy to take the potential of this form of market power more seriously. Deception, imperfect information and other "consumer protection" problems, when they have marketwide effects, and are not likely to be prevented by competition in the relevant market, should give rise to antitrust violations.

This is in part because they can cause harms to consumer welfare in addition to the higher prices they cause, including allocative inefficiency and umbrella effects. Antitrust remedies, including treble damages, are indeed appropriate for these situations. The single damages that would be awarded if these cases were tried as consumer protection violations, fraud, or business torts would provide significantly inadequate deterrence. ${ }^{36}$

For these reasons, as the agencies contemplate future dominant firm cases, they should give more attention to the possibility that "consumer protection" market failures might create market power even in relatively unconcentrated markets and by defendants with relatively modest market shares.

A more serious consideration of the market failures discussed in this statement also would be consistent with the ways we currently approach potential consumer protection violations. As noted earlier, in these cases we routinely look for market failures due to such factors as deception or imperfect information, and we certainly would not decline to prosecute a fraudulent seller just because it had a small market share or because most of the firms in its market were honest.

I urge the field to apply these insights more often in antitrust cases as well. As the agencies contemplate future dominant firm cases and any possible consensus statement over

36 See Robert H. Lande, Are Antitrust "Treble" Damages Really Single Damages? 54 Ohio State L.J. 115 (1993). This article demonstrates that antitrust's co-called "treble" damages, when viewed correctly and in light of optimal deterrence, really are only approximately single damages. A fortiori, damages that were only $1 / 3$ as large as antitrust damages would provide substantially inadequate deterrence. 
how to deal with single-firm conduct, they should not exclude the possibility that informational issues and other "consumer protection" market failures might create market power despite relatively low market shares. 